\title{
地球沙漠と月・火星沙漠の相違点 〜火星の表層物質と農業的利用の可能性〜
}

人間が行く月や火星で、どのようにして生態系が 成立するのか、さらに植物を含めた生物は本当に 共存できるのか、このような疑問を考える前にま ずはそのような環境を最初につくることが重要と 考えています。実際に月や火星で植物を栽培し、食 糧を生産するには与圧したドームが必要となるで しょう。植物に必要な太陽光はそこそこあります。 しかし、大気組成が問題になります。そして、植物 を育てるには、植物に必要な栄養をどのように管理 するのか、さらに人間を含めて地球から輸送する 生物に寄生する生物をどうコントロールするか... 種の起源や進化を考えると未体験での宇宙生活は 決して容易なものではありません。むしろ、人間の 他天体への進出は SF 映画に登場するような奇怪な 生物を誕生させるシーズになるかもしれません。

火星への移住を考えると、火星での大気で最も多 いのは二酸化炭素です。現在の火星の条件では、嫌 気的な生物はともかくとして、好気的な生物にとつ ては過酷な環境です。居住環境について水星から火 星までの惑星や地球の月の固体部分を比較してみ ると（図 1)、地球でわれわれが生活しているのは、 マントルの上にある地殼、さらにその上の土㙵層の ごく浅い表面部分の環境で制御されています。惑 星の表層物質がどのように形成されるかというと、 表層の下にある地殼から供給された鉱物資源が風 化されることによって、さまざまな土壤ができてい ます。

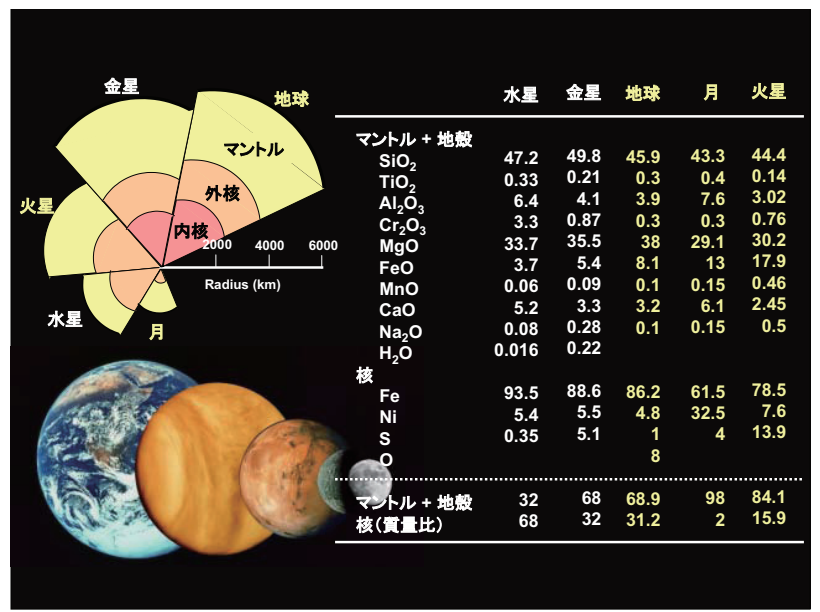

図 1 Comparison of solid planets and moon in the solar system

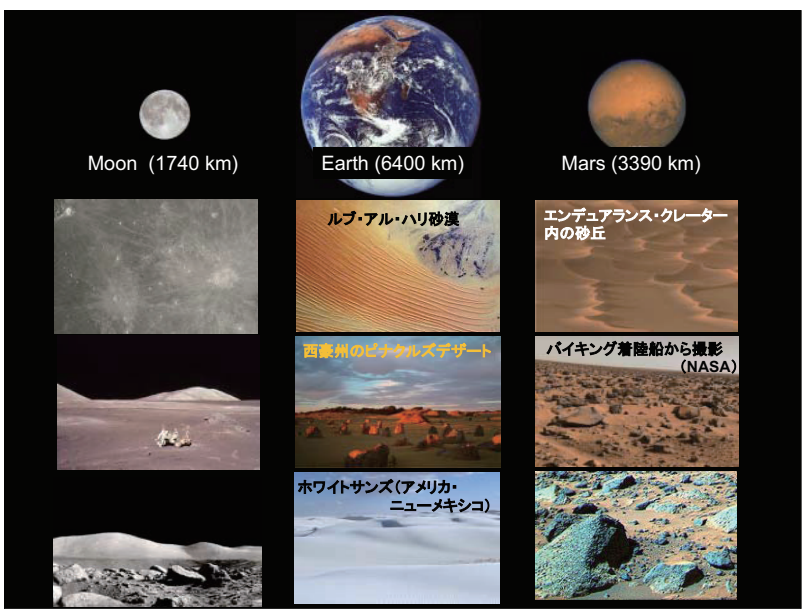

図 2 Surface scene of Moon, Earth and Mars

月をみても、火星で撮像された画像をみても、そ 机らの表面は地球の沙漠（=水の少ない不毛の地、 砂漠＝砂沙漠）と大して変わりません（図 2)。そ こは生物が住める環境ではないようにみえます。色 合いは、月であれば白くて、ニューメキシコのホ ワイトサンズに似ています。火星の赤い色合いは、 ルブ・アル・ハリ砂漠に似ています。火星で岩が散 在する風景は、オーストラリアのピナクルス砂漠の ようです。ただし、決定的に月や火星が地球と違う ことをあげると、地球の沙漠では鉱物としてあった ものが、大気や水により、また生物の作用もあるの ですが、物質としてどんどん分化してきていること

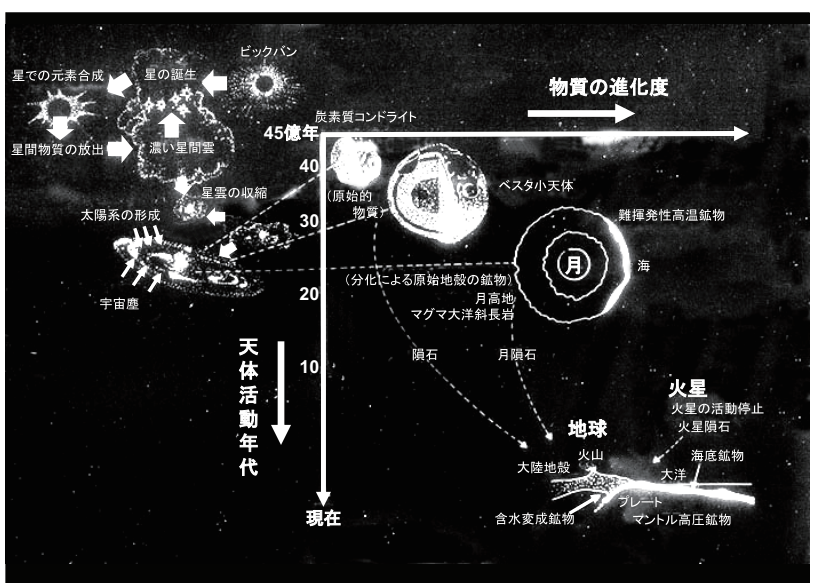

図 3 The evolition of cosmic materials with progress of planetary activities 


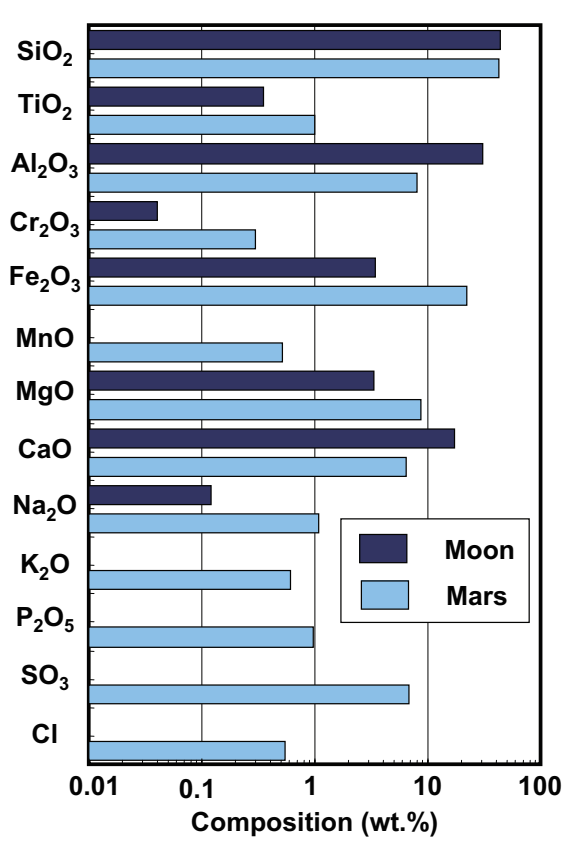

図 4 Composition of hte lunar and martian regolith. Data from Taylor (1975) and Brückner et al. (2001)

です。分化しきったあとの、砂だけとか、炭酸カル シウムあるいは石膏だけが、ある場所にあつまり、 そこでは生物が住めなくなっているところもあり ます。

しかし、月や火星では、そのような物質進化や分 化はほとんど進んでいません(図3)。月については、 とくに、進化・分化は皆無に近いのです。大気も水 もなく、ほとんど進化していない状態の鉱物にとど まっています。ところが、火星では、若干進化が 見られます。鉱物の種類をみると、月の高地に関し てはほとんどが斜長石でしめられています（図 4)。 斜長石が主成分の斜長岩、また暗色の海の部分では 玄武岩がほとんどです。

火星では、火星の隕石を分析した結果から、月と 同じく、斜長石と玄武岩がおもな成分です。そして、 火星では、大気や水と反応した物質が若干確認され ています。とくに生物をこれから生産していこうと する上で重要な水については、水の痕跡をしめす峡 谷の地形が観測されています。極冠の近くには表面 に凍った水がみつけられたり、表面直下からの中性 子のエネルギー分布から極以外の場所でも浅い層 に水のあることがわかっています。ただし温度は低 いので、水は凍った状態で存在します。

水は鉱物に作用してそれを変成させます。また大 気の作用も否定できませんが、水により層状になっ た地形も確認されています（図 5)。むかしに大洪

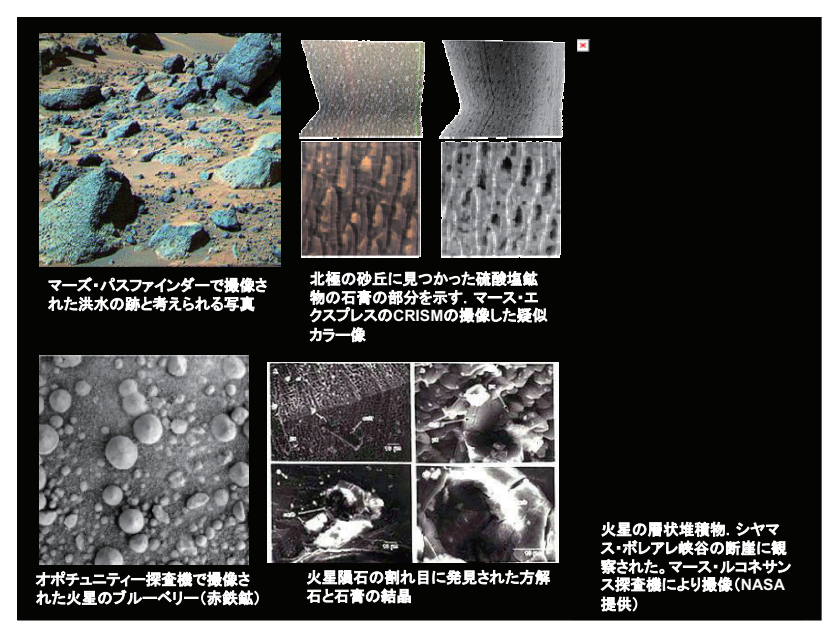

図 5 Evidence of action of water on Mars

水があったために、地表面の岩が特定の方向に向い ていたりしているところがあります。また微小な部 分をみると、通常の水と大気 (二酸化炭素) を取り こんだ鉱物・炭酸塩があったり、二酸化硫黄をとり こんだ石膏がみられたりします。またブルーベリー という名前のつけられた小さな球状の物体で、鉄が 溶脱したような赤鉄鉱があるのが確認されていま す。昔の火星には水が豊かにあり、大気中の二酸 化炭素や二酸化硫黄がとりこま机た酸性雨がふり、 岩石をどんどん溶かしていたのでしょう。そのよう な風化物が堆積している部位も火星にはあります。

液体の水に加えて、生物の痕跡も火星にあるらし いと唱えられています。南極で発見された火星隕石 において、炭酸塩の小さな円盤の周囲に磁鉄鉱の析 出がみられます。その析出のしかたは、地球でみら れる生物学的な作用による磁鉄鉱の析出と似てい ます。さらにその隕石の繴開面に微化石様の構造が

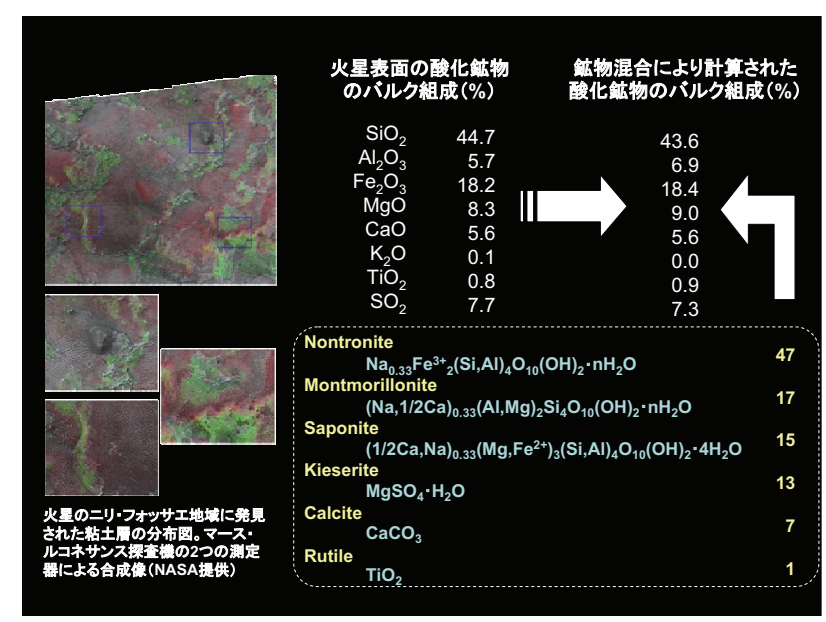

図 6 Distribution of clay minerals on Mars 
表 1 Dissolution rate of main minerals $\left(25^{\circ} \mathrm{C}, \mathrm{pH}=5\right)($ A.C. Lasaga, 1984)

\begin{tabular}{lcc}
\hline Mineral & $\begin{array}{c}\text { Dissolution rate } \\
\left(\mathrm{mol} / \mathrm{m}^{2} / \mathrm{s}\right)\end{array}$ & $\begin{array}{c}\text { Dissolution time of } \\
1 \mathrm{~mm} \phi \text { particle }(\mathrm{y})\end{array}$ \\
\hline Quartz & $4.1 \times 10^{-14}$ & $34,000,000$ \\
Muscovite & $2.6 \times 10^{-13}$ & $2,700,000$ \\
Mg-Olivine & $1.2 \times 10^{-12}$ & 600,000 \\
Orthoclase & $1.7 \times 10^{-12}$ & 520,000 \\
Albite & $1.2 \times 10^{-11}$ & 80,000 \\
Enstatite & $1.0 \times 10^{-10}$ & 8,800 \\
Diopside & $1.4 \times 10^{-10}$ & 6,800 \\
Nepheline & $2.8 \times 10^{-9}$ & 211 \\
Anorthite & $5.6 \times 10^{-9}$ & 112 \\
\hline
\end{tabular}

あるといわれたり、有機物である多環芳香族炭化水 素がふくまれているのがわかっています。

火星の中で狭い領域（ニリ・フォッサ工地域）で はありますが、粘土層の痕跡が見いだされていま す (図 6)。土畩構成成分として粘土は重要な役割 をもっています。火星表面の酸化鉱物のバルク組成 が測定されており、いくつかの粘土鉱物（モンモ リロナイト、ノントロナイト、スメクタイトなど） をまぜると、測定されている酸化鉱物の組成と近い 值になります。ただし、これはあくまでも参考值で すが、粘土鉱物の構成比により火星の模擬土㗒とし て使って実験している例もあります。酸化鉱物の組 成を、火星と月で比較すると、ケイ酸は同じですが、 アルミニウムは月でそこそこ多く、火星では鉄、マ グネシウムが多いことがわかります(図4)。ただし、 ここで比較しているのは月の高地であり、斜長石が 多いことから カルシウムは火星の方が若干少なく なっています。

火星の表面は、およそ玄武岩的な鉱物です。玄武 岩をつくるのは斜長石ですが、月にしろ火星にしろ 斜長石を多く含む造岩鉱物は多くあります。これは 何を意味するかというと、溶液の $\mathrm{pH}$ を 5 とすると、 $1 \mathrm{~mm}$ ほどの球状の斜長石は 100 年ほどで溶けてし まいます。これは、鉱物が再構築されるという意味

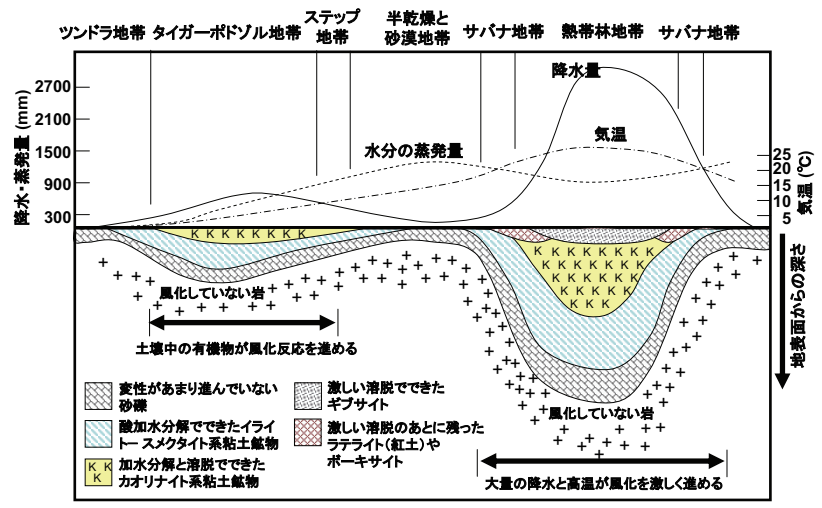

図 7 Layer structure and climate zone
表 2 Average chemical structure of two fulvic acids

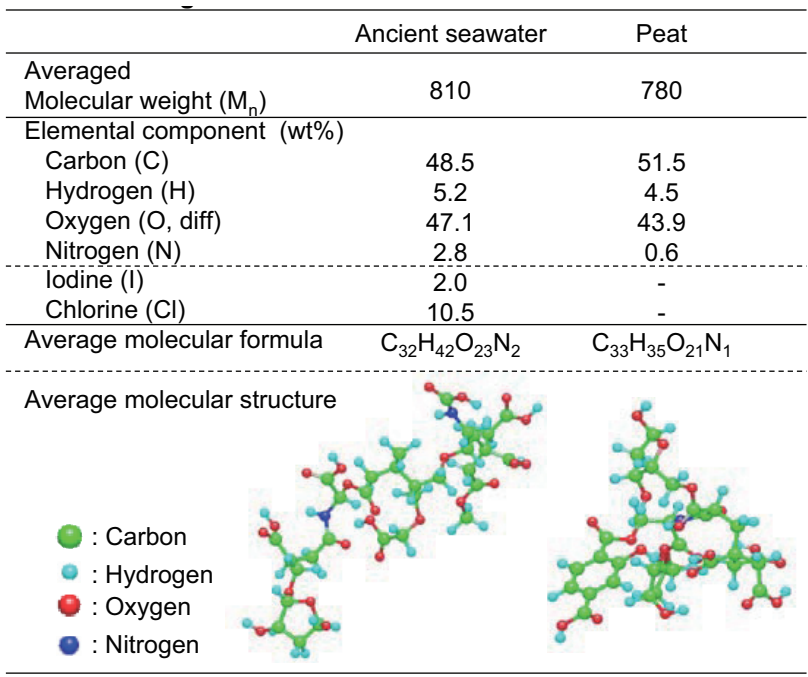

合いで、溶けるということで、他の鉱物とくらべる と、斜長石の溶解速度は早い造岩鉱物です (表 1)。 地球上の各気候帯でどのように風化物が堆積し ていくかを図 7 に示しています。表面近くに粘土 鉱物の層があり、上部にカオリン、その下に $2: 1$ 層 状珪酸塩鉱物であるスメクタイトの層があります。 火星の環境にもっとも近いのは、タイガ・ボドソル 地带であり、降雨量がすくなく、気温が低い地帯で す。火星でこれから風化が進行していけば、その地 帯の土壌ができていくものと考えられます。

地球上の土畩は、母材、気候、地形、生物、そし て時間などの要素因子により様々な様相を示しま すが、土壤を形成するときには、産生有機物によ る風化作用は重要な要素です。生物を育てるには、 まず土壌環境を最初につくる必要があります。そ

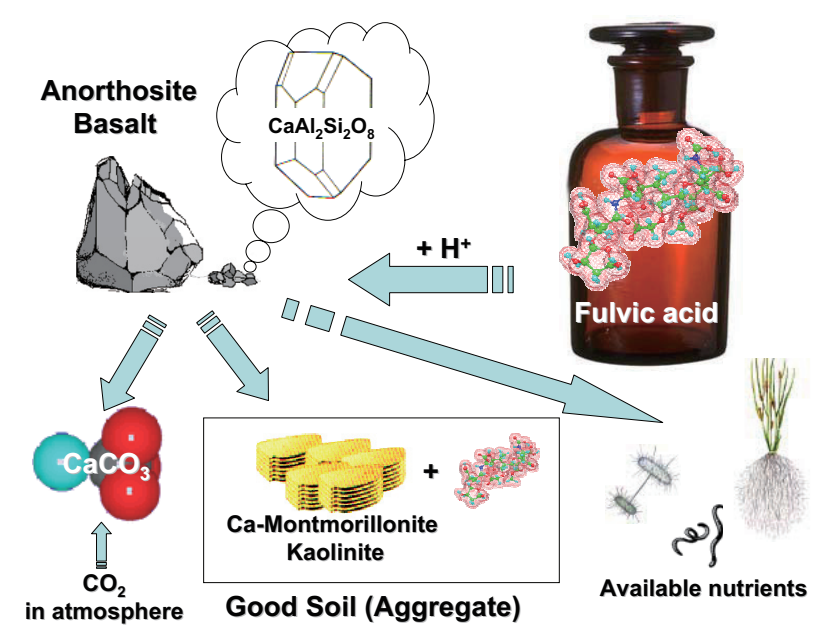

図 8 Action of fulvic acid in formation of soil 


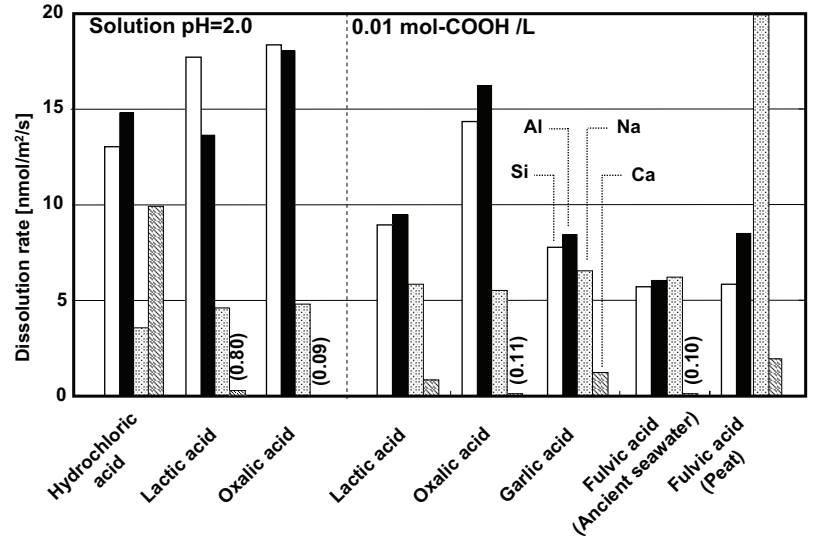

図 9 Composition of dissolution rate of plagioclase by acidic solution

のためには、生きた生物とその有機物を火星に持っ て行くのではなく、地球に産出する優秀な腐植物質 であるフルボ酸（表 2）を回収して火星表層に供給 すると、容易によい土壤ができると考えています。 そこでフルボ酸が優れた地球資源であることを実 証するために、地球上に豊富にある斜長石を使い、 フルボ酸溶液とまぜて、どのようにどのくらいの 速度で斜長石が溶けるかを実験的に調べました（図 8)。フルボ酸とか腐植物質は、土㙵学においてよ く知られています。フルボ酸の代表的な推定化学構 造をみると、多くのカルボキシル基をもっていま す。

フルボ酸は地球上の生物や生態系に大きな影響 をおよぼしている物質群です。フルボ酸が斜長石を 溶かすさまを、塩酸 ( $\mathrm{pH}$ 2) や、乳酸やシュウ酸といつ た有機酸での溶解と比べてみました（図 9)。ケイ 素とアルミニウムの酸化物は主要な造岩成分です が、 $\mathrm{pH} 2$ の塩酸には、1 日で直径 $1 \mathrm{~mm}$ の球が消失 するほどよく溶けますが、二次生成物として石英が 確認されました。有機酸では、その溶液の酸性度が 異なるので、カルボキシル基の濃度を同じにして比 較しました。シュウ酸では カルシウム酸化物は溶 けてもシュウ酸カルシウムとして再析出してしま います。フルボ酸では、他の有機酸と比べ構成元素 の溶出能が低いものの、一様に溶解していることが わかります。乳酸に関してはケイ素酸化物の溶解能 が高く、このことは粘土鉱物をつくるのに重要で す。実際にX 線回折像から、短時間でカオリナイ トができるのがわかり、斜長石から粘土鉱物に変換 できることが証明されています（図 10）。この過程 には $\mathrm{pH}$ の度合、ケイ素酸化物の溶解量、さらに反 応温度など様々な作用が関与し、生成する二次鉱物

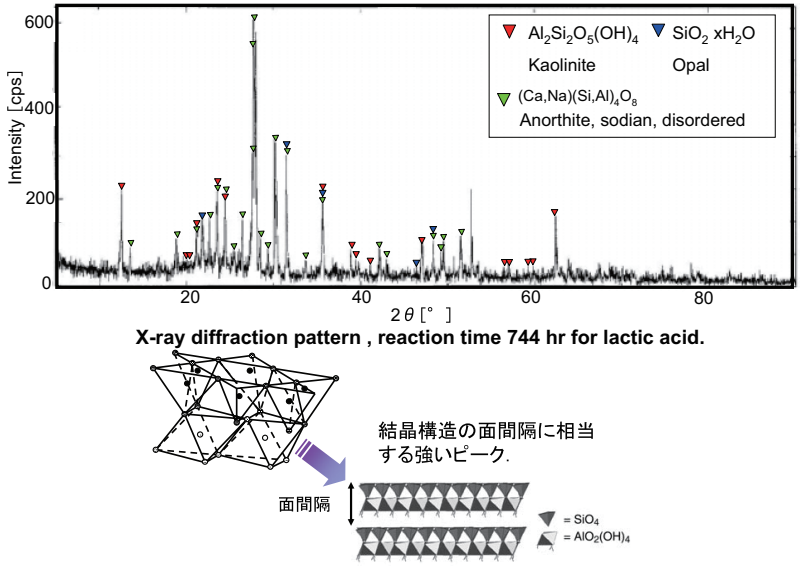

図 10 Formation of clay mineral

に影響を与えます。どのようにこれらを制御したら よいか今後の検討となりますが、一分子に多くの酸 性官能基をもつフルボ酸は無機酸や他の有機酸と 比べ多段階で解離しながら反応が進行しますので、 土壤構成成分で重要である粘土鉱物を生成するに は制御しやすい物質と予測されます。

フルボ酸は、強い植物生理活性も示します（図 11)。イネの苗にフルボ酸をあたえながら田植えを すると、根の成長が促進され、また茎も太くなりま す。フルボ酸の成長促進のしくみについては、様々 なことが考えられていますが、植物を育てるときに 重要なのは、栄養塩のコントロールであり、実は容 易なことではありません。イオン交換体としてはた らくカルボキシル基を多くもつフルボ酸は、まず水 中にある栄養塩イオンをとりこみ固定します。植物 は生長しつつ栄養塩を要求し、酸を放出します。フ ルボ酸は、植物から放出される酸の分だけ、栄養塩 イオンを放出して植物に供給します。すなわち植物 の成長に合わせて、それに応じた適正な量の栄養塩 を植物に供給する機能をフルボ酸はもっています。

実験で微生物を培養するときには、 $\mathrm{pH}$ を適正な 範囲に維持するために $\mathrm{pH}$ 緩衝液を培地に加えま す。ところで、フルボ酸は高い $\mathrm{pH}$ 緩衝能を有しま す（図 12）。生物にとっても、この緩衝機能は重要 です。つまり、生物が自分でだした酸で自分自身が

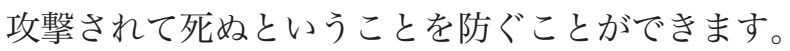
また、地球上での沙漠化土壤の修復に腐植物質は大 きなはたらきを示します。例えば、アルカリ・塩害 をひき起こしやすい土噮は粘土質であるので排水 性・通気性が悪く、毛管作用によりナトリウムが表 層に蓄積してさらに排水性が悪くなります。土壤の 排水性が悪くなったアルカリ性土袞に腐植物質を 


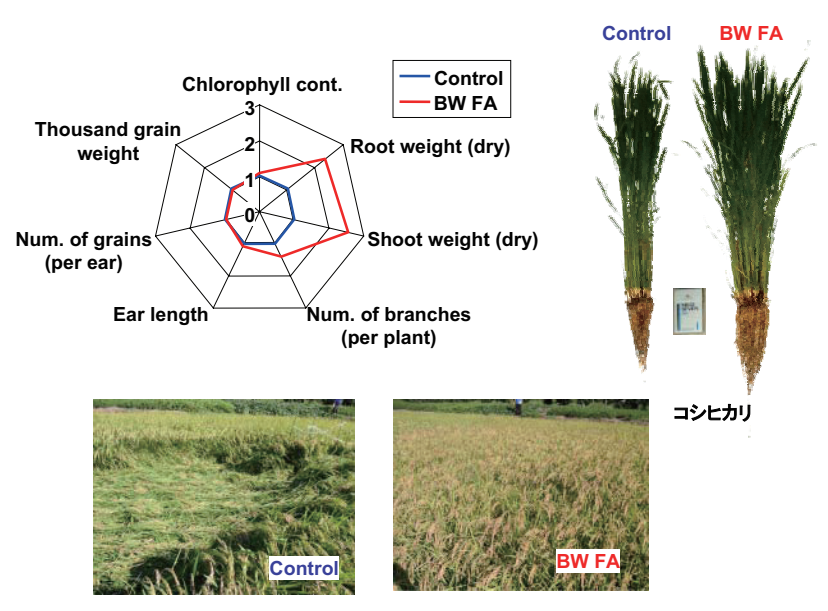

図 11 Physiological effects of fulvic acid

まぜると、ナトリウムが溶脱して根圈域の性状を改 良することができます（図 13）。逆に、酸性アルミ ニウム害をひき起こしやすい土壤は砂質であるの で排水性・通気性は高いのですが、イオン交換能 や $\mathrm{pH}$ 緩衝能に乏しく、さらに保水性が低いので易 溶性塩が溶脱されます。結果、鉱物中のアルミニウ ムが溶解し、アルミニウム毒により穀物の根の伸長 を停止させてしまいます。塩酸などの無機酸は酸性 度が高い分、斜長石の溶解性に優れているのですが （図 9)、アルミニウム毒による植物生長阻害をひき 起こす可能性が大いに考えられます。このような土 培に対しても腐植物質はアルミニウム毒を緩和す る作用もみられ、結果、栄養を吸収する根の成長が 衰えないという効果が証明されています（図 14）。

フルボ酸を用いて斜長石から粘土鉱物をつくり ますが、さらにつくられた粘土鉱物と腐植物質の複 合効果として、粒の凝集が起こります。粒の凝集が

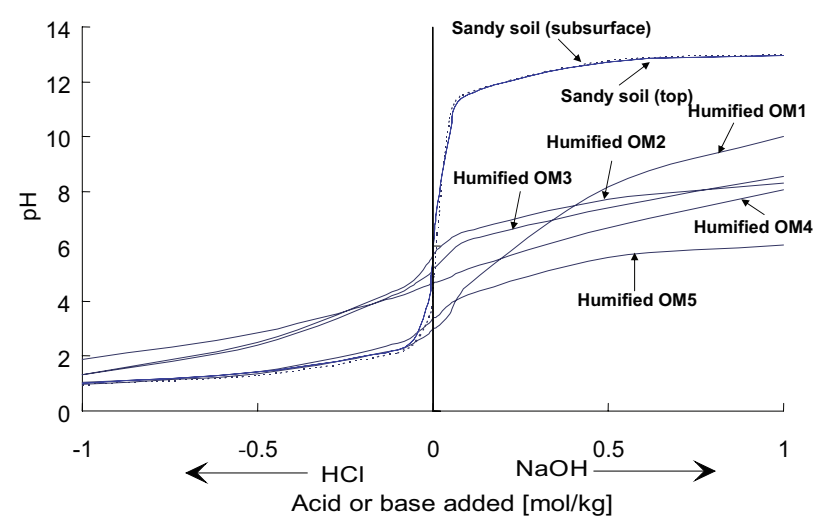

図 $12 \mathrm{pH}$ buffering curves of acid-affected arable soil and humified organic materilas

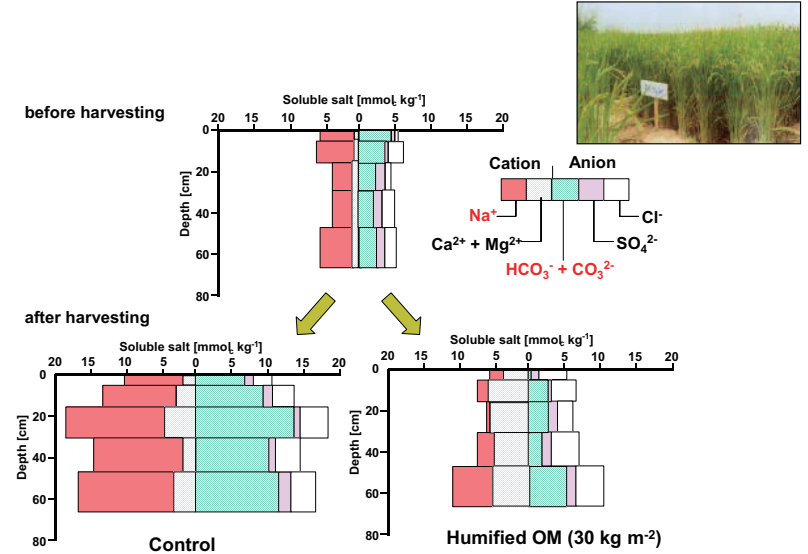

図 13 Influence of humified organic materials on alkaline salts content in rice field after harvesting

複雑な幾何学的形状になるにつれ、団粒構造ができ ます（図 15)。このようにしてできる団粒は、酸素 をこのむ好気性菌と、このまない嫌気性菌の双方 を凝集的に共存させて、双方の長所を発揮させま す（図 16）。例えば、腐植物質を生成するには、粗 大有機物を分解する好気性菌、その分解物を重縮合 させる嫌気性菌が必要となり、土壇環境が著しく好 気環境になると有機物の蓄積は低く、むしろ二酸化 炭素として分解されます。逆に嫌気環境になると腐 敗ガスを発生します。窒素固定の場合にも同様で窒 素固定菌は酸素を利用して呼吸しますが、窒素固 定を行うには酸素は不要となります。このように 土䘫中の生態系をコントロールして、有効活用す るにはスパーコンピューターでも難解な方程式（つ まり土壌環境）を付与してあげる必要があります。 団粒構造を即つくりたいのであれば、植物バイオ マスから生成した炭化物も一つの方法と考元ます。 この炭化物には植物組織を維持した幾何学的形状 をもつており、かつ炭素の塊ですからダイヤモンド ほどではありませんが極めて安定しています。われ われは、日本古代から行われている炭農法を改めて

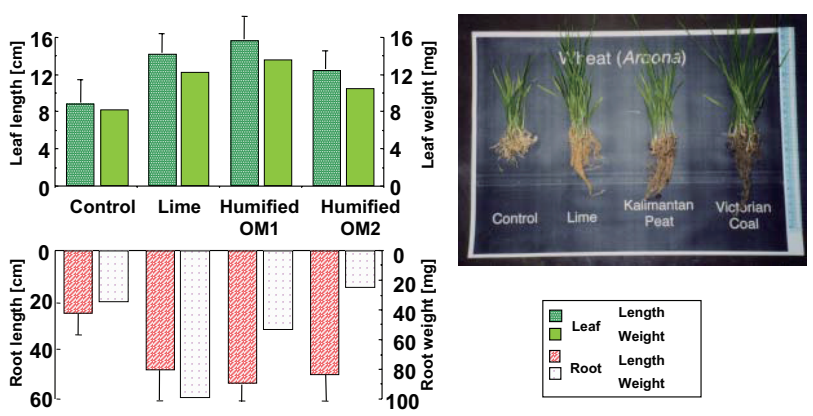

図 14 Comparison of wheat growth for Al-treated soils with lime and humified organic materials 

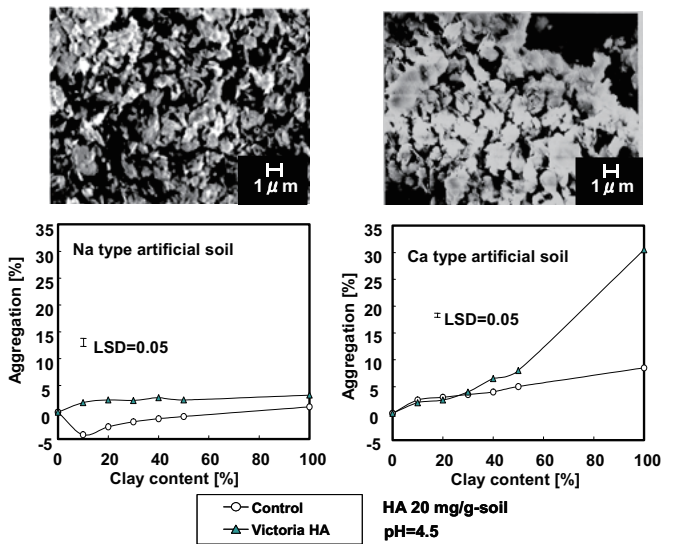

図 15 Aggregated fraction in humic acid adsorbed on $\mathrm{Na}-$, Ca-artificial soils

見なおし、土壌生物との親和性の高い炭化物の生成 も試みています。

最後に、火星の表層物質である斜長石を多く含む 玄武岩の資源的利用価値として（図 17）、今回の講 演題目である農業的利用のほかに、発電用の電子素 子、酸素ガス生成原料、そして建築資材としての利 用に期待されます。地球の沙漠とあきらかに異なっ ているのは、物質資源の分化が月や火星の沙漠はほ とんど進行していない点でしょう。他天体への移 住計画において真剣に考えなければならないのは、 人間の手でもう一つの地球沙漠 (不毛な地) を作っ てはならないこと、そして、根本的な素過程を理解 するなかでわれわれの生命体惑星の地球をどう維 持していくかでしょう。

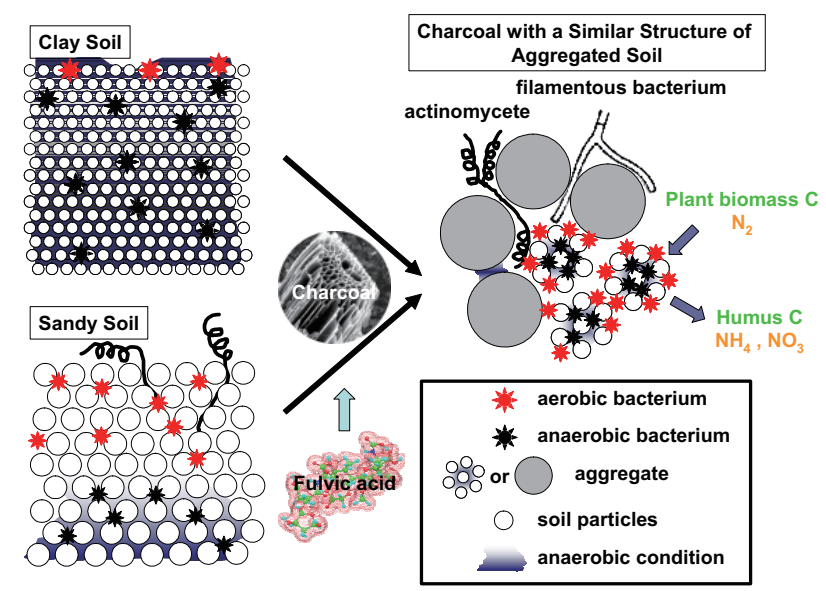

図 16 Function of soil aggregate

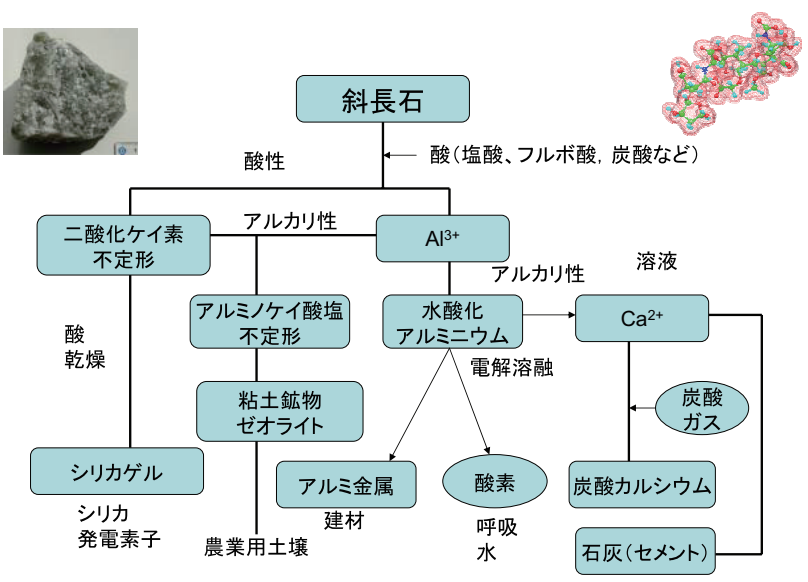

図 17 Strategy of soil formation on Mars

\section{Variation between Terrestrial and Lunar or Martian Desert - Surface Materials on Mars and its Possible Use for Agriculture}

\section{Yuuki Yazawa ${ }^{\dagger}$, Maiko Saito, and Hiroshi Takeda}

Chiba Institute of Technology

\section{Abstract}

In order to evaluate feasibility of synthesizing ecological system on Moon and Mars for sustaining human life there, it is required to prepare environment, which enables to support photosynthetic activity of plants. Surface materials, crust over mantle and thin soil layer, are important factor for life. Evolution of surface materials, including weathering of minerals, is compared between Earth, Moon and Mars.

To whom correspondence should be addressed:

Chiba Institute of Technology, 2-17-1 Tsudanuma, Narashino, Chiba 275-0016, Japan

E-mail: yuuki.yazawa@it-chiba.ac.jp 